\title{
Anal Squamous Zone
}

National Cancer Institute

\section{Source}

National Cancer Institute. Anal Squamous Zone. NCI Thesaurus. Code C32071.

The lower third segment of the anal canal. It is covered with stratified squamous epithelium. 